\title{
KEMAMPUAN BERBAHASA BALI PADA KALANGAN REMAJA DI DESA PAKRAMAN PERAUPAN DENPASAR
}

\author{
Oleh : I Gede Sudiarta \\ Guru Bahasa Bali Pada SMAN Baturiti
}

\begin{abstract}
In globalization era, language has an important place to build teenager orientation. Language could show someone and nation characteristic. Language is not only as a communication, but also as a processof human thinking to comprehend something objectively and imaginatively. It could show every aspect of human life. In addition, without language people will be noiseless and will die in the silent. One way to conserve Balinese language is increase teenager's interst. According to the explanation above, the problems in this research can be formulated as follows ; 1) how is the Balinese teenager's ability in using Balinese language in Peraupan Denpasar Village? 2) what are the factors that affect Balinese teenager's ability in using Balinese language in Peraupan Denpasar village? 3) what are the efforts that can be used to increase Balinese teenager's ability in using Balinese language in Peraupan Denpasar village?. Theories that was used in this research were sociolinguistics theory, language attitude theory, social changes theory and learning motivation theory. This research used some data collection techniques, such as observation, interview and literature. Data which have been collected was proceed and analysed by using qualitative descriptive method. The result of this research showed that as follows; 1) Balinese teenager's ability in using Balinese in Peraupan Denpasar village is still low if it is connected to sor singgih, 2) the factors that that can affect Balinese teenager's ability in using Balinese language in Peraupan Denpasar village are technology, environment, and the difficulties of Balinese language also less of tools and infrastructure, 3) the efforts that could be done to solve the problem are making a contest, doing pasraman activity, using Balinese language (sor singgih) in meeting, upgrading parents role, an upgrading school role.
\end{abstract}

Key words : Ability, Balinese language, teenager.

\section{PENDAHULUAN}

Dewasa ini arus globalisasi melanda tata kehidupan sosial masyarakat Bali. Hampir semua lini dalam kehidupan masyarakat Bali dipengaruhi oleh perkembangan global yang sulit untuk dikendalikan. Perkembangan global, pada satu sisi mendorong perubahan masyarakat ke arah yang lebih baik dan mapan. Misalnya, perkembangan teknologi komunikasi dapat mempermudah relasi dalam masyarakat. Hal ini terlihat dalam produksi alat-alat komunikasi yang canggih, seperti telepon genggam (hand phone), televisi (TV) dan internet. Pada sisi lain, perkembangan global membawa masyarakat ke arah yang negatif. Misalnya, egois, apatis, dan menampilkan gaya hidup yang tidak sesuai dengan kaidah-kaidah masyarakat Bali. Masyarakat Bali yang 
dimaksud dalam konteks ini adalah masyarakat Bali yang sudah heterogen dalam artian sudah berbaur dengan etnis-etnis lainnya. Pengaruh globalisasi dan masyarakat multikultural tersebut mempengaruhi kesadaran, sikap dan tindakan sebagian masyarakat Bali terhadap bahasa Bali sebagai salah satu identitas budayanya.

Hal ini sangat tampak dalam fenomena kurangnya penggunaan bahasa Bali dalam komunikasi masyarakat Bali di Kota Denpasar. Sebaliknya orang cenderung mengikuti gaya hidup wisatawan asing sebagai akibat dari aktivitas pariwisata di Kota Denpasar, selain itu masyarakat Bali di Kota Denpasar hampir sebagian besar menggunakan bahasa Indonesia atau bahasa asing daripada menggunakan bahasa Bali (Suarjana, 2008 : 8). Keadaan tersebut akan lebih parah oleh adanya berbagai tekanan-tekanan, baik dari dalam maupun dari luar. Dari dalam, orang Bali sendiri kalau berbahasa Bali jika diperhatikan lebih seksama, terutama dalam pergaulan pada tingkat elit (tokoh-tokoh panutan) sudah mulai jarang yang mampu berbahasa Bali yang baik dan benar sesuai dengan tatanan bahasa atau sor singgih. Disamping faktor dari dalam, faktor dari luar masih banyak lagi sebagai penyebab berkurangnya minat remaja dalam mempelajari bahasa Bali. Salah satunya semakin berkembangnya teknologi seperti internet, handphone dan siaran televisi. Hal ini tampak dalam lingkup pergaulan masyarakat multikultural di Kota Denpasar baik di lingkungan kerja, keluarga maupun di masyarakat, yang dominan menggunakan bahasa Indonesia, bahkan terkadang menggunakan bahasa campuran antara bahasa Indonesia dengan bahasa Bali, bahasa Indonesia dengan bahasa asing daripada menggunakan bahasa Bali yang utuh.

Kondisi demikian nampaknya semakin meluas hingga kelapisan masyarakat pedesaan. Berdasarkan studi awal, peneliti banyak menemukan penggunaan bahasa Bali yang tidak benar atau bercampur bahasa Indonesia.
Misalnya, dalam pesangkepan (rapat) di banjar, seorang pemimpin dalam masyarakat (Kelian) membuka sesi tanya jawab dengan mengatakan "sadurung lanjut, mungkin wenten sane jagi bertanya indik masalah puniki. Silahkan angkat tangan, langsung manten pertanyaannya nggih.." Setelah selesai pemimpin menutup pertemuan dengan mengatakan, "Bapak dan Ibu serta warga yang hadir, suksma nggih atas kehadirannya dalam rapat kita malam ini." Contoh tersebut mungkin atau seringkali didengar pada rembug keluarga atau pasangkepan (rapat). Ini membuktikan penggunakan bahasa Bali masih belum seutuhnya dipergunakan, masih juga terdapat unsur bahasa Indonesianya.

Kemampuan berbahasa Bali dikalangan anak-anak dalam pergaulannya juga sangat kurang, bahkan dalam kehidupan keluarga, orangtua jarang mengarahkan anaknya menggunakan bahasa Bali, dan bahkan bangga apabila anaknya fasih berbahasa Indonesia atau bahasa asing sejak usia dini. Di lingkungan pendidikan dari tingkat Taman Kanak-Kanak (TK), Sekolah Dasar (SD), sampai dengan tingkat Perguruan Tinggi, lebih dominan belajar bahasa asing (Inggris) dari pada bahasa Bali dan bahasa Indonesia. (Sugono, 2007: 162). Dengan demikian penggunaan bahasa Bali di Kota Denpasar mengalami pergeseran dan penurunan drastis.

Bertolak dari uraian di atas walaupun bahasa Bali merupakan ciri penting untuk menentukkan identitas keetnikan suatu kelompok, nampaknya bahasa Bali tidak selalu dapat dipertahankan namun bukan berarti bahasa Bali harus ditinggalkan begitu saja. Bahasa Bali justru harus didayagunakan agar budaya yang adi luhung tidak tercerabut dari akarnya. Dalam menghadapi guncangan perubahan sosial yang begitu cepat dan kuat, pemertahanan bahasa Bali dalam masyarakat multikultural di Kota Denpasar merupakan upaya yang relevan untuk mempertahankan bahasa Bali sebagai salah satu warisan leluhur sejak dahulu kala. 
Berdasarkan fenomena yang terjadi di Desa Pakraman Peraupan Denpasar tersebut, maka dapat merumuskan beberapa permasalahan, yaitu: 1) Bagaimana kemampuan berbahasa Bali pada kalangan remaja di Desa Pakraman Peraupan Denpasar? 2) Faktorfaktor apa saja yang mempengaruhi kemampuan berbahasa Bali pada kalangan remaja di Desa Pakraman Peraupan Denpasar? 3) Upaya apa saja yang dilakukan untuk meningkatkan kemampuan berbahasa Bali pada kalangan remaja di Desa Pakraman Peraupan Denpasar?

Dalam penelitian ini, peneliti menggunakan teknik penentuan informan yaitu purposive sampling, dimana teknik pengumpulan data yang dipakai adalah observasi non partisipan, wawancara terbuka yang standar, dan studi kepustakaan. Sesuai data yang dikumpulkan dari metode pengumpulan data tersebut, maka langkah-langkah analisis data dengan merujuk langkah-langkah analisis data yang dilakukan seperti yang diungkapkan oleh Kaelan (2005:69) sebagai berikut : 1) Reduksi Data, 2) Klasifikasi Data, 3) Display Data, dan 4) Memberikan Interpretasi dan mengambil keputusan data yang berupa uraian verbal senantiasa diberikan Interpretasi kemudian diberikan suatu penafsiran sesuai dengan konteks data yang telah dikumpulkan.

\section{HASIL DAN PEMBAHASAN PENELITIAN}

\subsection{Lokasi dan Kondisi Desa Pakraman Peraupan}

Penelitian ini dilaksanakan di Desa Pakraman Peraupan Denpasar. Desa Pakraman Peraupan yang berlokasi di wilayah Kecamatan Denpasar Utara memiliki kondisi geografis yang secara umum berada di ketinggian 0-75M dari permukaan laut. Morfologi landai dengan kemiringan lahan sebagian besar antara $0-5 \%$. Secara kualitatif masyarakat Desa Pakraman Peraupan meskipun sudah merupakan masyarakat perkotaan namun semangat relawan dan kegotong-royongan masih sangat baik.

Ditinjau dari letak geografis, Desa Pakraman Peraupan adalah bagian dari desa adat peguyangan kangin. Desa adat Peguyangan kangin ini terdiri dari 9 banjar yang terletak di Kota Denpasar. Kesembilan banjar ini di bagi lagi menjadi 3 banjar, ketiga banjar inilah yang disebut dengan Desa Pakraman Peraupan. Luas Desa Pakraman Peraupan $\pm 200 \mathrm{Ha}$, dengan lahan terdiri dari perumahan dan pertokoan hanya sedikit digunakan lahan pertanian dan perkebunan. Desa Pakraman Peraupan terdiri dari 3 Banjar yaitu : Banjar Jurang Asri, banjar Pengukuh, dan Banjar Bantas. Desa Pakraman Peraupan. Jumlah penduduk Desa Pakraman Peraupan Denpasar, Bila dilihat dari situasi penduduknya, penduduk desa Peraupan berjumlah 1220 jiwa yang tersebar dalam $403 \mathrm{KK}$ yang merupakan warga asli Desa pakraman Peraupan.

Keadaan sosial budaya di Desa pakraman Peraupan pada dasarnya sangat beragam karena terdapat suku-suku Jawa dan Bali yang berbaur dalam kebudayaan yang berbeda dan saling melengkapi satu sama lainnya. Banyaknya suku Jawa dan Bali dikarenakan banyak sekali pendatangpendatang dari luar desa maupun dari luar daerah yang ingin menetap di Desa pakraman Peraupan. Masyarakat yang tinggal di desa tersebut memeluk beberapa Agama diantaranya Agama hindu, Kristen, Islam, dan Budha mereka berbaur dalam satu-kesatuan struktur masyarakat sosial yang harmonis dan saling mendukung.

\subsection{Kemampuan Berbahasa Bali Pada Kalangan Remaja Di Desa Pakraman Peraupan Denpasar}

Pengaruh lingkungan yang berbeda antara keluarga, masyarakat, dan sekolah dalam perkembangan bahasa akan menyebabkan perbedaan antara anak yang satu dengan yang lain. Hal ini ditunjukkan dengan pemilihan dan 
penggunaan kosa kata sesuai dengan tingkat sosial keluarganya. Keluarga dari masyarakat lapisan berpendidikan rendah atau buta huruf akan banyak menggunakan bahasa pasar, bahasa sembarangan, dengan istilah-istilah yang kasar. Masyarakat yang terdidik yang pada umumnya memiliki status sosial yang baik, akan menggunakan istilah-istilah yang lebih efektif, dan pada umunya anak-anak remajanya juga juga berbahasa secara lebih baik (Sumarsono, 2009).

Hidup bermasyarakat di Bali, berarti harus bisa berbahasa Bali. Tata cara berbicara berbahasa Bali apabila dilihat dari struktur kebahasaannya itu sangat rumit dan diperlukan waktu yang lama untuk memahaminya. Keanekaragaman masyarakat Bali khususnya di Desa Pakraman Peraupan yang berbeda berdasarkan golongan dan status sosialnya. Jika belajar berbicara harus berdasarkan struktur yang tepat mengenai kebahasaan, maka tidak akan jarang remaja Bali khususnya para remaja yang ada di Desa Pakraman Peraupan banyak yang akan meninggalkan penggunaan bahasa Bali dan beralih kebahasa lain yang dianggap lebih mudah, apalagi dengan adanya pengaruh perkembangan jaman dan teknologi yang semakin canggih dan modern. Tentu dengan keadaan tersebut akan berpengaruh terhadap perkembangan bahasa Bali khususnya pada kalangan remaja di Desa Pekraman Peraupan Denpasar.

Berdasarkan teori sikap bahasa menurut Garvin dan Mathiot (Jendra, 2011: 110), sikap bahasa yang positif terkait dengan beberapa hal, yaitu kesetiaan bahasa, kebanggaan bahasa, dan kesadaran adanya norma bahasa. Penuturan informan di atas jelas menyebutkan bahwa kemampuan masyarakat khususnya kalangan remaja dalam berbahasa Bali sangat kurang, dan bahkan dianggap tidak penting, bahasa lain cenderung lebih penting, lebih menjanjikan mendapatkan hasil apabila dihubungkan dengan pekerjaan. Fenomena ini tentu sudah merupakan penyelewengan bahasa, ketidaksetiaan terhadap bahasa sendiri, kebanggaan terhadap jati diri mulai pudar. Fenomena ini menjadi tantangan dalam perkembangan bahasa Bali dimana bahasa Bali yang saat ini sudah mulai ditinggalkan, bahkan penggunaan kesehariannya pun masih bercampur dengan bahasa lainnya. Permasalahan ini harus segera diatasi salah satunya dengan menguatkan kembali kesadaran para remaja akan pentingnya melestarikan bahasa Bali yang merupakan jati diri orang Bali.

Bertolak dari pemaparan tersebut, dengan kemajuan di bidang ilmu pengetahuan dan teknologi, yang semua serba mengarah ke halhal yang bersifat modern, kemampuan berbahasa Bali di Desa Pakraman Peraupan fungsinya mulai bergeser, minat masyarakat untuk mempelajari dan menggunakan bahasa Bali secara mendalam mulai berkurang. Hal ini juga dapat dilihat dari kegiatan-kegiatan seperti rapat rutin (pasamuan), kumpul-kumpul remaja dan kegiatan sejenis lainnya. Apalagi yang terjadi di kalangan remaja, minat untuk mempelajari bahasa Bali sudah semakin rendah sehingga kemampuan untuk berbahasa Bali menjadi rendah. Masalah tersebut disebabkan beberapa faktor diantaranya tingkat kesulitan dari bahasa Bali jika dihubungkan dengan sor singgih basa, faktor lingkungan sekitar yang selalu mengajarkan bahasa Bali hanya bersifat lumrah.

Informasi yang lebih akurat juga didapatkan bahwa kemampuan berbahasa Bali pada kalangan remaja di Desa Pakraman Peraupan tidak konsisten dalam penggunaan kesehariannya. Hal ini dikarenakan semakin berkembangnya Ilmu Pengetahuan dan Teknologi seperti (internet, facebook, twitter dan sejenisnya), kurangnya jam pelajaran khusus berbahasa Bali yang diperoleh di bangku sekolah, dan yang paling membingungkan adalah tingkat kesulitan dari bahasa Bali itu sendiri (sor singgih basa), sehingga tidak dapat dipungkiri kemampuan penggunaan bahasa Bali dalam kehidupan sehari-hari semakin menurun. 
Seiring dengan berkembangnya ilmu pengetahuan dan teknologi, menyebabkan sor singgih bahasa Bali yang ada di Desa Pakraman Peraupan mengalami pergeseran fungsi dan kadang kala mulai ditinggalkan oleh pengempu bahasa Bali itu sendiri. Minat dan kemampuan berbahasa Bali masyarakat Desa Pakraman Peraupan secara umum masih sangat rendah terutama yang berhubungan dengan tingkat tutur (sor singgih basa). Permasalahan ini dapat dilihat dari berbagi kegiatan yang dilaksanakan di Desa Pakraman Peraupan yang umumnya menggunakan sor singgih bahasa Bali sebagai pengantarnya seperti kegiatan rapat Sekaa Teruna Teruni, Pasraman, kegiatan Dharma Wecana, Penyuluhan tentang bahasa Bali, kegiatan keagamaan yang mendatangkan sulinggih, masyarakat di Desa Pakraman Peraupan sangat jarang yang mempunyai kemampuan berbicara menggunakan bahasa Bali yang sesuai dengan tingkatannya dengan sulinggih.

Ditelusuri lebih lanjut, bahasa Bali yang ada di Desa Pakraman Peraupan sifatnya sangat beragam seperti misalnya pada kalangan orang yang lebih tua pengunaan bahasa Bali alus lebih dominan dilakukan karena dianggap masih biasa dan mudah dibandingkan menggunakan bahasa Indonesia. Penggunaan bahasa Bali kalau dilihat dari sisi remaja dan anak-anak sudah mulai berkurang karena dianggap sulit dan menakutkan jika dibandingkan dengan bahasa Indonesia. Oleh karena itu pada kalangan remaja dan anak-anak bahasa yang lumrah digunakan adalah bahasa campuran (bahasa Bali andap yang disisipi bahasa Indonesia).

Kondisi demikian nampaknya semakin meluas hingga kelapisan masyarakat pedesaan yang salah satunya adalah di Desa Peraupan. Hal ini dilihat pada beberapa situasi krama banjar dalam sangkepan/paruman, rembugrembug keluarga besar serta rapat STT atau sangkepan Sekaa Teruna, yang mampu menggunakan bahasa Bali sesuai dengan sor singgih basa hanya orang-orang tertentu
(Bendesa Adat, Penyarikan, Kelian, Perbekel serta tokoh masyarakat). Masyarakat umum hanya sebagian kecil yang mampu menggunakan sor singgih basa dan kebanyakan hanya menggunakan bahasa Bali lumrah (andap) bahkan bahasa Bali kasar. Keberadaan ini bisa disebabkan adanya penyusupan dari unsur-unsur bahasa Indonesia dan bahasa asing. Hal inilah yang menjadi fakta bahwa kurang positifnya penutur bahasa Bali akhir-akhir ini di lingkungan masyarakat.

Minat belajar bahasa Bali pada kalangan remaja di Desa Pakraman Peraupan saat ini tergolong masih sangat rendah bila dibandingkan dengan remaja jaman dahulu, hal itu dapat dilihat dari penelitian yang dilaksanakan bahwa remaja yang ada di Desa Pakraman Peraupan sebagian besar tidak bisa menggunakan bahasa Bali secara benar (sesuai sor singgih basa). Mengukur kemampuan seseorang memang sangat sulit namun seperti kenyataan yang penulis lihat di Desa Pakraman Peraupan itu sendiri tentang kemampuan berbahasa Bali kalangan remaja itu benar-benar memprihatinkan karena sebagaimana penulis amati sejauh ini remaja yang ada di Desa Pakraman Peraupan semakin hari semakin enggan belajar bahasa Bali terutama yang berkaitan dengan sor singgih basa Bali.

Permasalahan ini seharusnya tidaklah lepas dari peran orang tua, karena dalam hal ini peran orang tua sangatlah penting dalam mengajarkan anak-anak mereka berbahasa Bali yang baik dan benar, guna melestarikan budaya Bali dan melestarikan bahasa Bali itu agar tidak punah serta ditinggalkan oleh pengempunya yang dalam hal ini adalah orang Bali sendiri atau masyarakat Bali.

\subsection{Faktor-Faktor Yang Mempengaruhi Kemampuan Berbahasa Bali Pada Kalangan Remaja Di Desa Pakraman Peraupan Denpasar}

Terkait dengan kemampuan berbahasa Bali pada kalangan remaja telah diadakan 
beberapa upaya untuk menanggulanginya. Semua informan mempunyai pendapat yang hampir sama tentang faktor-faktor yang mempengaruhi kemampuan berbahasa Bali pada kalangan remaja. Faktor-faktor tersebut dapat dikemukakan sebagai berikut:

\subsubsection{Faktor Teknologi}

Kemajuan teknologi yang semakin pesat merupakan salah satu sebagai faktor yang mempengaruhi kemampuan berbahasa Bali pada kalangan Remaja khususnya di Desa Pakraman Peraupan. Media elektronik adalah salah satu media modern yang dapat menunjang dan menghambat minat belajar bahasa Bali pada kalangan remaja di Desa Pakraman Peraupan Denpasar. Salah satu media elektronik yang dimaksudkan adalah siaran di televisi dan radio. Siaran televisi dan radio masih kurang acaraacara seperti siaran berbahasa Bali, dharma wacana yang berbahasa Bali, lagu-lagu berbahasa Bali sertahiburan yang menggunakan bahasa Bali sebagai pengantarnya.

Bahasa Bali saat ini tidaklah menjadi pilihan bagi kalangan remaja, karena dalam pikiran mereka hanyalah bahasa Indonesia dan bahasa gaul yang sesuai dengan umur mereka. Lain halnya dengan program-program yang berkaitan dengan bahasa Bali seperti Gita Shanti, Tembang-tembang Bali, Orti Bali serta lainnya yang ditayangkan Bali TV. Media televisi ini selain merupakan faktor penghambat, juga merupakan salah satu faktor penunjang mempertahankan bahasa Bali. Akan tetapi keberadaan program-program tersebut haruslah konsisten ditayangkan. Frekuensi siaran tersebut harus konsisten ditayangkan, yaitu setiap hari dalam waktu yang sama, sehingga masyarakat penontonnya kecintaan terhadap bahasa Bali mulai tergugah bangkit dan merasa memiliki.

Dengan keberadaan Bali TV sebagai media lokal yang menasional dalam hal penayangan dan berita-berita daerah tentu sangat penting. Pihak media juga menyadari bahwa bahasa Bali merupakan unsur budaya Bali yang semakin terpinggirkan oleh pesatnya kemajuan teknologi dalam hidup masyarakat kota Denpasar. Untuk itu Bali TV memanfaatkan perannya sebagai media elektronik untuk selalu menampilkan acaraacara berbasis bahasa Bali, dimana seiring begitu banyaknya bermunculan media televisi lainnya yang menampilkan acara-acara berbeda yang tidak mengutamakan unsur daerah khususnya bahasa Bali.

Disamping dari media televisi dan radio, dibidang telekomunikasi juga dapat mempengaruhi penggunaan bahasa Bali, yaitu dengan kemajuan teknologi telepon genggam (HP) yang sudah menjadi kebutuhan pokok dari manusia itu sendiri. Dibidang lain yang mengalami kemajuan adalah semakin gampangnya akses internet yang memudahkan manusia untuk mencari informasi-informasi terbaru yang berkembang. Dengan semakin mudahnya orang membuka internet, menyebabkan pola pikir manusia sudah semakin mengglobal (mendunia). Selain itu, peranan media cetak seperti koran, majalah dan sejenisnya juga dianggap masih kurang memadai jika dikaitkan dengan bahasa Bali itu sendiri. Rubrik yang menggunakan bahasa Bali hanya terbit pada hari minggu saja itupun hanya beberapa baris saja yang melampirkan pembahasan yang berkaitan dengan bahasa Bali.

\subsubsection{Faktor Lingkungan}

Seperti yang diketahui bahwa dalam belajar bahasa, tidak dapat dilakukan dalam keadaan sepi tetapi harus membutuhkan interaksi dengan orang lain. Terdapat beberapa hal yang penting dalam perkembangan bahasa yaitu perubahan kultural dan konteks sosiokultural bahasa, dukungan terhadap bahasa dan pandangan behavioral. Interaksi dengan orang lain sudah tentu dapat dilakukan dalam lingkup suatu lingkungan, baik lingkungan keluarga, sekolah, maupun masyarakat. 


\section{Lingkungan keluarga}

Keluarga merupakan wadah yang pertamatama dan merupakan dasar yang fundamental bagi perkembangan dan pertumbuhan anak, kebiasaan yang dilakukan orang tua sehari-hari memberikan warna dasar terhadap pembentukan kepribadian anak dan ini dapat menjurus kearah positif atau kearah negatif. Akan tetapi pengaruh itu tidaklah terbatas kepada waktu setelah menjadi remaja saja, akan tetapi telah dimulai sejak dari bayi, bahkan sejak dalam kandungan. Penggunaan bahasa, khususnya di kalangan keluarga muda di kawasan perkotaan di Bali lebih cenderung berkomunikasi dengan menggunakan bahasa Indonesia, terutama dalam mendidik serta menjalin komunikasi dengan anak-anaknya. Sehingga, para pengamat bahasa dan sastra mengkhawatirkan bahwa bahasa Bali, khususnya bahasa Bali halus akan mengalami kepunahan.

\section{Lingkungan Sekolah}

Lingkungan sekolah sangat memungkinkan berkembangnya atau terhambatnya proses perkembangan penyesuaian diri. Umumnya sekolah dipandang sebagai media yang sangat berguna untuk mempengaruhi kehidupan dan perkembangan intelektual, sosial, nilai-nilai, sikap dan moral remaja . Ini berarti bahwa sekolah tidak hanya berfungsi memberikan pengajaran dan pendidikan secara formal yang mempengaruhi pembinaan remaja, karena seorang guru bagi muridnya tidak hanya merupakan pengajar yang memberikan ilmu dan keterampilan baginya, tetapi guru dalam pembinaan remaja. Lingkungan sekolah tidak menjamin penggunaan bahasa Bali digunakan secara konsisten, terutama pada saat pelajaran bahasa Bali. Bahasa Bali yang seharusnya digunakan sebagai bahasa pengantar dalam pelajaran bahasa Bali terkadang tampak bahkan sering pemakaian kata-katanya berasal dari bahasa yang berbeda (bahasa Indonesia) dengan bahasa yang sedang kita gunakan. Hal ini adalah salah satu wujud konkret dari fenomena yang disebut kontak bahasa (Jendra 2011:55).

Terkait dengan hal tersebut, kepopuleran bahasa Indonesia dan upaya bertahan bahasa Bali sebagai salah satu identitas budaya, masyarakat sangat mengharapkan kepada pihak sekolah sebagai salah satu sarana pendidikan dalam pengembangan bahasa. Perkembangan bahasa Bali, baik sebagai unsur budaya dan identitas masyarakat Bali maupun sebagai alat komunikasi, sangat bergantung pada bagaimana upaya pihak sekolah dalam mengembangkan kurikulum bahasa sebagai mata pelajaran yang wajib ditempuh para anak didik. Terkait hal ini, kebijakan Dinas Pendidikan sangat mendukung dengan dijadikannya mata pelajaran bahasa Bali sebagai mata pelajaran yang wajib ditempuh oleh semua anak didik, baik di sekolah dasar (SD) maupun sekolah lanjutan (SMP dan SMA). Oleh karena itu, masyarakat Bali sangat mengharapkan kebijakan itu terus dipertahankan karena lingkungan sekolah merupakan unsur pembinaan yang penting bagi remaja setelah lingkungan keluarga.

\section{Masyarakat}

Perkembangan bahasa remaja dilengkapi dan diperkaya oleh lingkungan masyarakat di mana mereka tinggal. Bersamaan dengan kehidupannya di dalam masyarakat luas, anak(remaja) mengikuti proses belajar di sekolah. Pengaruh pergaulan di dalam masyarakat terkadang sangat menonjol, sehingga bahasa anak (remaja) menjadi lebih diwarnai pola bahasa pergaulan yang berkembang di dalam kelompok teman sebaya.

Semakin sering dan luas pergaulan orang Bali dengan orang-orang dari suku lain di Indonesia, semakin tinggi pula tingkat pemakaian bahasa Indonesianya. Begitu juga semakin banyak wisatawan asing yang datang ke Bali semakin tinggi tingkat ketertarikan orang Bali untuk menguasai bahasa Inggris agar bisa 
berinteraksi dengan wisatawan-wisatawan tersebut. Seperti halnya bahasa Indonesia, secara perlahan bahasa Inggris kini telah menjadi bahasa yang tidak asing lagi bagi kebanyakan orang Bali. Hal tersebut berarti munculnya variasi pemakaian bahasa Bali yang bercampur dengan bahasa Inggris dan bahasa lain (Iwan Indrawan Jendra, 2011:41).

Bahasa Bali seperti yang dipergunakan dalam pergaulan di Desa Pakraman Peraupan adalah pemakaian bahasa Bali yang sudah bercampur dengan bahasa Indonesia dan bahasa Inggris. Hal inilah sebagai salah satu faktor masih rendahnya kemampuan berbahasa Bali. Terkait dengan hal tersebut, pengaruh lingkungan yang berbeda antara keluarga, masyarakat, dan sekolah dalam perkembangan bahasa akan menyebabkan perbedaan antara anak yang satu dengan yang lain. Hal ini ditunjukkan dengan pemilihan dan penggunaan kosa kata sesuai dengan tingkat sosial keluarganya. Keluarga dari masyarakat lapisan berpendidikan rendah atau buta huruf akan banyak menggunakan bahasa pasaran, bahasa sembarangan, dengan istilah-istilah yang kasar, tetapi tetap konsisten menggunakan bahasa Bali walaupun disisipi bahasa lainnya. Masyarakat yang terdidik yang pada umumnya memiliki status sosial yang baik, akan menggunakan istilah-istilah yang lebih efektif, dan pada umunya anak-anak remajanya juga berbahasa secara lebih baik bahkan jauh lebih modern, hanya saja bahasa utamanya bahasa Bali yang digunakan tidak konsisten bahkan terkadang tidak menggunakannya sama sekali dalam berkomunikasi dengan sesama.

\section{Kebudayaan}

Setiap kebudayaan memiliki norma-norma tertentu yang mengatur kepentingan manusia sebagai anggota masyarakat agar dapat terpelihara ketertiban dan keamanan sesuai dengan apa yang diharapkan. Pengaruhpengaruh kebudayaan asing baik melalui media massa (film, surat kabar, majalah dan sebagainya), maupun yang disaksikan langsung dapat berakibat positif dan negatif dalam perkembangan kepribadian remaja.

Perkembangan global dibantu media yang canggih memungkinkan arus informasi yang begitu padat dan deras menyerang generasi muda. Benturan budaya yang mau tak mau akhirnya juga benturan norma berakibat terjadinya pergeseran nilai hampir disemua kehidupan, gaya hidup global mewarnai generasi muda hanyut terbawa arus serba barat yang menembus budaya-budaya lokal yang berakar religi. Imperialisme kebudayaan tengah berlangsung menyusup kesemua sudut negeri melalui tularan media informasi dan komunikasi atau dibawa langsung oleh para wisatawan. Dampak pergaulan hidup global telah menunjukkan tanda-tanda mencemaskan terutama dalam kehidupan remaja, yang merupakan tumpuan harapan bangsa sebagai generasi penerus dan pewaris kebudayaan.

\subsubsection{Faktor Tingkat Kesulitan Serta Kurangnya Sarana dan Prasarana}

Bahasa Bali merupakan bahasa ibu yang sangat perlu dilestarikan, mengingat di tengah kehidupan modern yang multikultural bahasa Bali semakin jarang digunakan. Bahkan yang lebih ironis sebagian orang yang mengklaim dirinya sebagai masyarakat modern berpendapat bahwa menggunakan bahasa Bali adalah kembali ke zaman dahulu, ketinggalan zaman, alias kampungan. Sangat disayangkan anak-anak yang kebetulan berada di komunitas kultur, dalam hal ini di perkotaan, sangat jarang dijumpai para remaja mampu berbahasa Bali karena orangtuanya enggan mengajarkan bahasa ibu tersebut kepada anaknya. Para orangtua bahkan senang dan bangga apabila anaknya fasih berbahasa Indonesia atau bahasa lainnya. Selain faktor internal dalam keluarga, faktor lingkungan juga sangat berperan terhadap lestarinya bahasa Bali, khususnya di Bali.

Terlepas dari persoalan tersebut bila hendak melestarikan bahasa Bali agar tidak 
punah dari para penuturnya, pada umumnya kita terjebak pada persoalan-persoalan praktis yang tengah dihadapi masyarakat Bali pada umumnya. Seperti kurangnya minat orang mempelajari bahasa Bali karena adanya persoalan anggah-ungguhing basa Bali yang dianggap terlalu sulit dan menakutkan. Kurangnya praktek berbahasa Bali sebagai salah satu penyebab mengapa bahasa Bali itu sulit untuk dipelajari. Seharusnya pelajaran bahasa Bali yang diterima selanjutnya diimbangi dengan praktek berbahasa Bali baik dimasyarakat, keluarga, maupun di sekolah. Hal ini tentu akan sangat berdampak pada kefasihan anak dalam berbahasa Bali. Tidak hanya teori saja yang didapat, tetapi praktek langsung juga harus dilaksanakan. Itulah permasalahan dalam bahasa Bali yang dianggap aktual, yang menyebabkan bahasa Bali tidak bisa berkembang.

Selain tingkat kesulitan tersebut ada juga faktor lain seperti misalnya kurangnya sarana dan prasarana yang berbasis bahasa Bali. Sarana dan prasarana yang dimaksud adalah jika dilihat di tempat-tempat umum seperti perpustakaan, buku-buku yang menggunakan bahasa Bali jumlahnya tidak memadai bahkan terkadang tidak tersedia. Bila dilihat dari sudut yang lebih khusus, yaitu khususnya di daerah pedesaan yang dalam hal ini adalah Desa Pakraman Peraupan, buku-buku berbahasa Bali yang bisa dijadikan acuan dalam berbicara didepan umum seperti misalnya rapat atau paruman sangat minim adanya. Selain itu, perpustakaan umum di daerah tersebut juga tidak ada, hanya tersedia di sekolah-sekolah saja bahkan belum terlihat lengkap dan belum memenuhi standar. Semua permasalahan tersebut merupakan salah satu faktor kesulitan dan kendala dalam mempelajari bahasa Bali, dan menjadi salah satu faktor yang mempengaruhi kemampuan berbahasa Bali pada kalangan remaja di Desa Pakraman Peraupan.

\subsubsection{Faktor Pariwisata}

Dapat diketahui bahwa hampir sebagian masyarakat di Bali bekerja dan mempertaruhkan nasibnya pada bidang-bidang yang berkaitan dengan pariwisata, sehingga dampak dari pariwisata itu sendiri sebagai hasilnya dapatlah membantu kesejahteraan masyarakat yang ada di Bali pada umumnya. Tersebarnya lapangan pekerjaan yang lebih banyak terkait pariwisata dapat memberikan peluang pekerjaan lebih banyak terhadap masyarakat di Bali, terkait dengan masyarakat adat, dampak positif yang dapat dipetik adalah dimana diberikannya peluang terhadap masyarakat adat yang memiliki keseniankesenian yang khas di masing-masing daerah untuk memperkenalkan dan sekaligus menjadikan sebagai suatu penghasilan bagi masyarakat tersebut.

Selain dampak baik, pastinya ada dampak buruk dari pariwisata itu sendiri terhadap masyarakat adat bali, dimana penyaringan kebudayaan yang tak bisa dikendalikan sering menimbulkan dampak buruk terhadap pola hidup masyarakat adat itu sendiri serta tanpa disadari mulai terkikisnya kebudayaan dan kearifan lokal masyarakat adat itu sendiri, apabila masyarakat tidak bisa mengendalikan arus pengaruh pariwisata tidak bisa dipungkiri bahwa kebudayaan yang menjadi objek dari pariwisata dan wisatawan akan terkikis oleh kebudayaan asing yang dibawa wisatawan itu sendiri, sehingga dampaknya akan berpengaruh buruk juga terhadap mata pencaharian masyarakat itu sendiri. Dimana pengaruhpengaruh tersebut mengakibatkan suatu perubahan sosial, dimana bisa perubahan yang dikehendaki ataupun yang tidak dikehendaki, dimana perubahan yang dikehedaki tersebut pastinya adalah perubahan yang dianggap baik oleh masyarakat terkait dengan dampak pariwisata yang akan mengakibatkan perubahan masyarakat di berbagai bidang.

Jadi segala hal pastilah memiliki dampak 
baik dan buruk, begitu pula dengan pariwisata itu sendiri yang dimana kendati telah lama melekat terhadap kehidupan masyarakat di Bali namun tetap saja memiliki dampak-dampak yang terkadang bisa baik, bisa buruk terhadap keberadaan bahasa Bali pada masyarakat Bali khususnya pada kalangan remaja di desa Pakraman Peraupan Denpasar. Dampak positif tentu dapat kita terima dengan baik dan dijadikan pedoman, tapi dampak negatif seharusnya kita buang dan menolak pengaruhpengaruh tersebut dengan melaksanakan berbagai daya upaya yang dilaksanakan oleh pemerintah dan warga Bali khususnya demi kelangsungan kelestarian bahasa Bali kedepannya.

\subsection{Upaya yang Dilakukan Untuk Meningkatkan Kemampuan Berbahasa Bali pada Kalangan Remaja di Desa Pakraman Peraupan Denpasar}

Upaya-upaya untuk melestarikan bahasa Bali terus dilakukan, baik oleh perorangan, kelompok maupun pihak pemerintah antara lain : (1) Melalui kegiatan berbagai jenis lomba berbahasa Bali (pidarta, dharma wecana, sambrama wecana, nyastra, satua-satua Bali, dan sebagainya). (2) Melalui siaran-siaran radio, televisi, dan surat kabar. (3) Melalui kegiatan penyuluhan-penyuluhan kepada masyarakat menyangkut betapa pentingnya penggunaan bahasa Bali. (4) Melalui kegiatan seminar dan bermacam-macam kegiatan yang sejenisnya. Namun semua kegiatan tersebut belum membuahkan hasil yang maksimal, karena kegiatan tersebut lebih banyak bersifat sementara, sehingga perlu ditingkatkan lagi menjadi kegiatan yang bersifat rutinitas dan dibutuhkan masyarakat.

Upaya yang perlu diadakan diantaranya segala kegiatan lomba yang berkaitan dengan bahasa Bali, dalam kegiatan rapat STT ataupun kegiatan kepemudaan lainnya, selalu menggunakan bahasa Bali sebagai pengantarnya. Disamping itu perlu diadakan pasraman tingkat remaja, dimana materi yang diberikan harus yang berkaitan dengan penggunaan bahasa Bali. Sehingga dengan kegiatan semacam ini, diharapkan dapat meningkatkan kemampuan berbahasa Bali pada kalangan remaja khususnya di Desa Pakraman Peraupan Denpasar. Beberapa pendapat dari informan dapat disimpulkan solusi atau upaya yang bisa dilakukan oleh masyarakat Desa Pakraman Peraupan dan remaja pada khususnya untuk meningkatkan kemampuan berbahasa Bali yang baik dan benar, sebagai berikut :

\subsubsection{Menggunakan Bahasa Bali Dalam Kegiatan Adat (rapat)}

Adat adalah sebuah kegiatan, perbuatan yang lazim diturut atau dilakukan sejak dahulu kala, cara kelakuan yang sudah menjadi kebiasaan (Departemen Kebudayaan dan Kebudayaan, 1990:5). Masyarakat Bali pada umumnya dikenal sebagai masyarakat yang sangat konsisten dengan kegiatan adat istiadat dalam keseharian hidupnya. Kegiatan adat istiadat dan kebiasaan yang sudah lazim dipraktikkan misalnya kegiatan sangkep, baik sangkep Desa, sangkep Teruna-Teruni, sangkep Subak, maupun peminangan.

Sangkep (rapat) adalah kegiatan adat yang bertujuan untuk mempersatukan pemikiran atau ide-ide antar warga se-desa dalam lingkup desa adat tertentu untuk mencapai kata sepakat. Dalam kegiatan sangkep terutama pada sangkep Teruna-Teruni, penggunaan bahasa Bali seharusnya sangat komunikatif digunakan oleh pemimpin sangkep maupun pada anggotanya. Tetapi yang penulis amati, belakangan kondisi seperti ini sudah mengalami degradasi (penurunan) penggunaan, Sehingga perlu ditingkatkan kembali khususnya mulai dari tingkat remaja sampai masyarakat secara umum. Di kalangan remaja perlu di biasakan menggunakan bahasa Bali yang sesuai dengan tingkatannya dalam kegiatan rapat serta kegiatan-kegiatan lainnya, bahkan harus sebagai rutinitas yang harus diterapkan 
penggunaannya, supaya kemampuan penggunaan bahasa Bali semakin terbiasa. Pada saat rapat, perlu sesekali mengundang penglingsir adat, maupun tokoh warga lainnya sebagai pemberi motivasi, dukungan terhadap segala kegiatan yang akan dilaksanakan, disamping itu para penglingsir ini sudah tentunya akan memberikan masukan yang berkaitan dengan melestarikan budaya Bali, tradisi Bali dan sudah tentunya bahasa Bali itu sendiri.

\subsubsection{Mengadakan Lomba}

Upaya yang telah dilakukan untuk meningkatkan kemampuan berbahasa Bali pada kalangan remaja di Desa Pakraman Peraupan Denpasar, salah satunya dengan mengadakan lomba. Kegiatan lomba yang dimaksud adalah kegiatan yang bertujuan untuk menumbuhkan minat para remaja dalam melestarikan budaya khususnya bahasa Bali. Lomba-lomba yang dimaksud seperti : masatua, pidato bahasa Bali, menulis aksara Bali, serta menyalin huruf latin ke akasara Bali. Dengan kegiatan-kegiatan seperti ini diharapkan para remaja yang ada di Desa Pakraman Peraupan semakin termotivasi dan lebih bersemangat dalam mempelajari bahasa Bali.

Lomba masatua dapat melatih daya ingat remaja tentang bahasa yang dipelajarinya dalam kondisi dan keadaan yang berbeda. Kegiatan ini bertujuan untuk meningkatkan kemampuan berbicara dengan menggunakan bahasa Bali yang sesuai dengan tingkatannya. Aspek yang paling ditonjolkan adalah kemampuan remaja dalam mengenal bahasa serta bisa menceritakan kembali cerita yang sudah dibaca. Adapun satua yang dilombakan adalah satua yang sudah dikenal dan memasyarakat. Hal ini bertujuan agar para remaja lebih mudah untuk mempelajarinya, sehingga diharapkan adanya keinginan yang lebih untuk membaca dan mempelajari satua. Lomba mesatua ini diadakan setiap perayaan ulang tahun sekaa teruna di Desa Pakraman Peraupan, disamping untuk belajar, juga secara tidak langsung melestarikan budaya mesatua.

\subsubsection{Kegiatan Pasraman}

Kata pasraman berasal dari kata "asrama" (sering ditulis dan dibaca ashram) yang artinya tempat berlangsungnya proses belajar mengajar atau pendidikan. Pendidikan pasraman menekankan pada disiplin diri, mengembangkan akhlak mulia dan sifat-sifat yang rajin, suka bekerja keras, pengekangan hawa nafsu dan gemar untuk menolong orang lain. Konsep pasraman yang berkembang sekarang diadopsi dari sistem pendidikan Hindu zaman dahulu di India, sebagaimana disuratkan dalam kitab suci Weda dan hingga kini masih tetap terpelihara.

Pasraman merupakan kegiatan yang dilakukan di tiap-tiap desa adat dengan berbagai tujuan didalamnya. Peserta kegiatan pasraman meliputi anak-anak dan remaja. Kegiatan ini bertujuan untuk melatih anak-anak dan remaja agar mengenal berbagai hal tentang kegiatan keagamaan, adat, dan khususnya penggunaan bahasa Bali dalam berbagai kegiatan. Dengan pasraman diharapkan para generasi muda yang ada di desa mempunyai kemampuan lebih berbahasa Bali dalam kegiatan sehari-hari.

\section{SIMPULAN}

Berdasarkan hasil penelitian yang dilakukan di Desa Pakraman Peraupan Denpasar, maka dapat disimpulkan sebagai berikut :

1. Kemampuan berbahasa Bali pada kalangan remaja di Desa Pakraman Peraupan Denpasar saat ini tergolong masih rendah, ini disebabkan karena bahasa Bali sangat sulit jika dihubungkan dengan sor singgih. Disamping itu kebiasaan remaja di Desa Pakraman Peraupan hanya menggunakan bahasa Bali lumrah dalam kehidupannya sehari-hari, bahkan lebih sering menggunakan 
bahasa Indonesia karena pergaulan masyarakat yang multikultural.

2. Faktor-faktor yang mempengaruhi kemampuan berbahasa Bali pada kalangan remaja di Desa Pakraman Peraupan Denpasar adalah faktor teknologi, faktor lingkungan, faktor tingkat kesulitan serta kurangnya sarana dan prasarana dalam pembelajaran, dan faktor pariwisata. Semua faktor-faktor tersebut sangat mempengaruhi keberadaan bahasa Bali dalam masyarakat khususnya pada kalangan remaja yang saat ini masih diragukan penggunaan dan kemampuan mereka dalam berbahasa Bali yang baik dan benar sesuai aturan dan norma sopan santun yang ada dalam masyarakat.

3. Upaya-upaya yang dapat dilakukan untuk meningkatkan kemampuan berbahasa Bali pada kalangan remaja yang ada di Desa Pakraman Peraupan Denpasar adalah dengan berbagai cara yaitu melalui kegiatan pasraman, mengadakan lomba-lomba, menggunakan bahasa Bali sesuai sor singgih dalam setiap kegiatan rapat, meningkatkan peranan orang tua agar mengajarkan bahasa Bali pada anaknya sejak dini, peranan sekolah sebagai ujung tombak agar ditingkatkan, serta pemerintah supaya mengupayakan untuk menambah jam pelajaran bahasa Bali di sekolah dan menambah tenaga guru bahasa Bali yang sesuai dengan keahliannya.

\section{DAFTAR PUSTAKA}

Balai Bahasa Denpasar. 1985. Kamus BaliIndonesia. Denpasar: Penerbit Balai Bahasa.

Campbell, Tom. 1994. Tujuh Teori Sosial ; Sketsa, Penilaian, Perbandingan. Yogyakarta: Penerbit Kanisius.

Chaer, Abdul. 2007. Linguistik Umum. Jakarta : Rineka Cipta.
Daradjat, Zakiah. 1991. Ilmu Jiwa Agama. Cet. XIII; Jakarta: Bulan Bintang

Emzir. 2007. Metodologi Penelitian Pendidikan. Jakarta: PT Raja Grafindo Persada.

Gumilar, 2007, dalam http//www.google.co.id).

Kridalaksana, Harimurti. 1984. Kamus Linguistik. Edisi kedua. Jakarta : penerbit PT Gramedia.

Mantra, IB. 1990. Bali : Masalah Sosial Budaya. Denpasar : Upada Sastra

Poerwadarminta. 1976. Kamus Umum Bahasa Indonesia. Jakarta: Balai Pustaka.

Pitana, I Gde. 1994. Dinamika Masyarakat dan Kebudayaan Bali. Denpasar : Offset BP

Suasta, Ida Bagus Made. 1986. Kedudukan dan Fungsi Bahasa Bali. Denpasar: Jurusan Bahasa Daerah Fakultas Sastra Universitas Udayana.

Suarjana, 2008. Sor Singgih Bahasa Bali Dalam Bahasa dan Kebudayaan. Singaraja: Rhika Dewata

Suarjana, Putra I Nyoman. 2011. Sor Singgih Bahasa Bali (ke-bali-an Manusia Bali Dalam Dharma Peparikan, Pidarta, Sambrama Wecana dan Dharma Wecana). Denpasar: PT. Tohpati Grafika Utama.

Suandi, 1996. Pemakaian Tingkat Tutur Bahasa Bali. Denpasar : Pustaka Bali Post

Sumarsono. 2009. Sosiolinguistik. Yogyakarta : Sabda dan Pustaka Pelajar

Tinggen, I Nengah. 1995. Sor Singgih Basa Bali. Singaraja: Rhika Dewata.

Teeuw, A. 1984. Sastra dan Ilmu Sastra. Pengantar Teori Sastra. Jakarta. Pustaka Jaya. 